\title{
Investigating the use of innovative mobile pedagogies for school-aged students: A systematic literature review
} Kevin Burden ${ }^{\mathrm{a}, *}$

k.j.burden@hull.ac.uk

\section{Matthew Kearney ${ }^{\mathrm{b}}$}

Sandra Schuck

Tony Hall

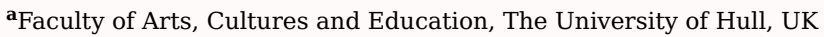

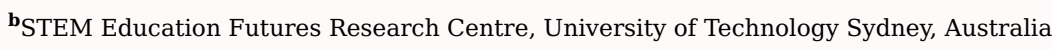

'School of Education, National University of Ireland, Galway, Ireland

${ }^{*}$ Corresponding author.

Abstract

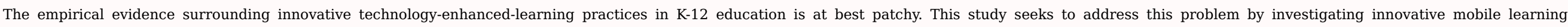

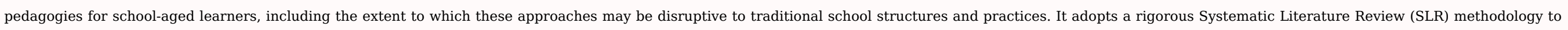

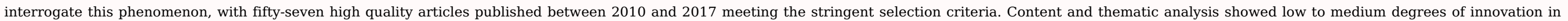

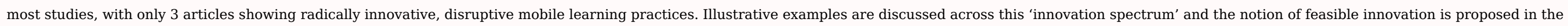

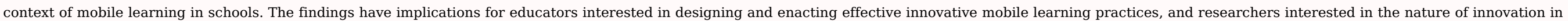
mobile pedagogies.

Keywords: Innovation; Disruption; Transformation; Mobile learning; Mobile pedagogies; Systematic literature review

\section{Introduction}

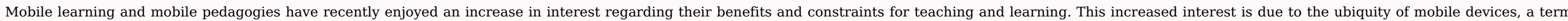

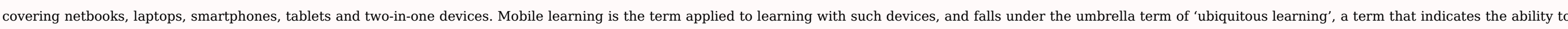

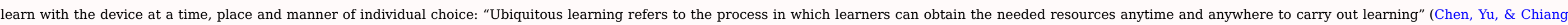
2017, p. 127). Ubiquitous learning or u-learning emphasises the contextualised and situated learning that is provided by use of mobile devices (Pegrum, Oakley, \& Faulkner, 2013).

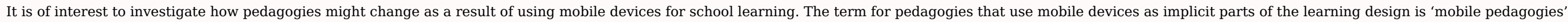

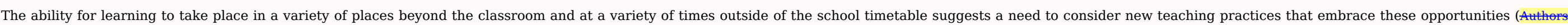

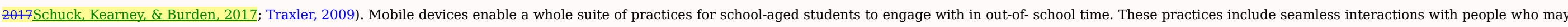

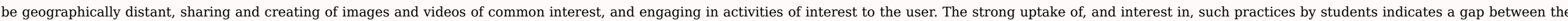

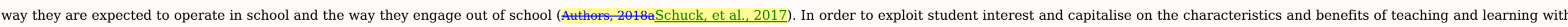

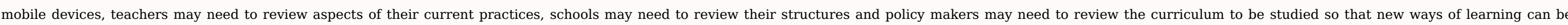

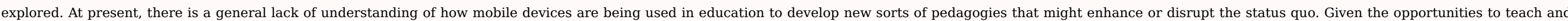




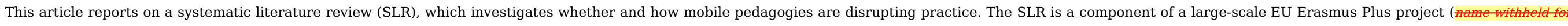

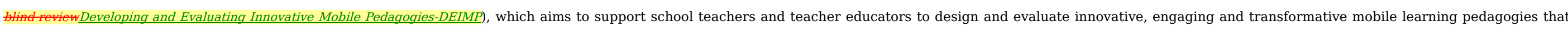

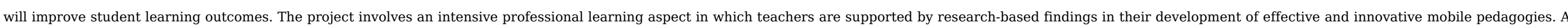

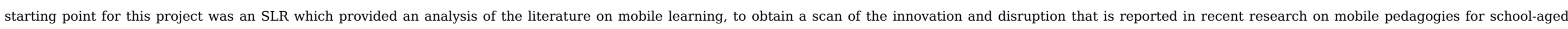
learners. This article discusses the SLR that provides this scan. The research questions for this SLR are:

1. What do innovative and disruptive mobile pedagogies for school-aged learners look like?

2. To what extent do innovative mobile pedagogies disrupt structures and practices of teaching and learning for school-aged learners?

\section{Background}

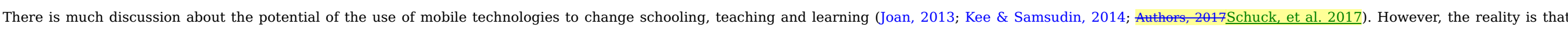

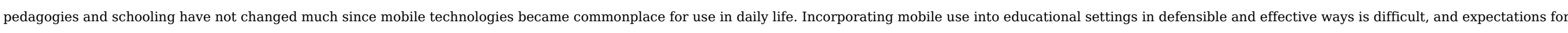

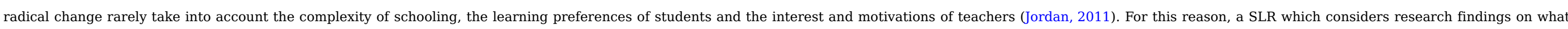
actually is occurring in teaching and learning of school-aged students is necessary. This article responds to this need.

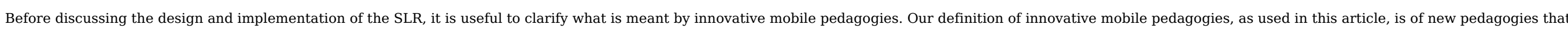

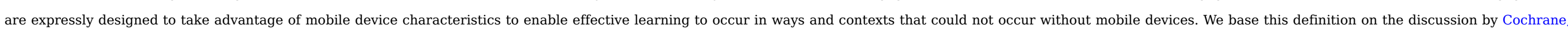

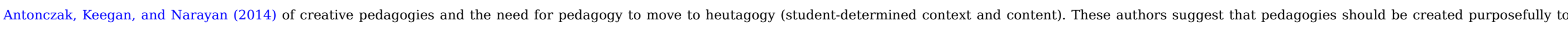

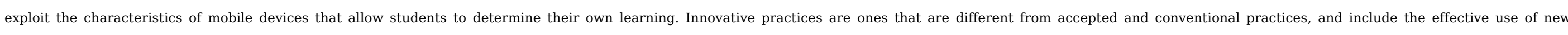

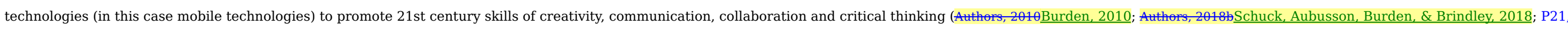
2007).

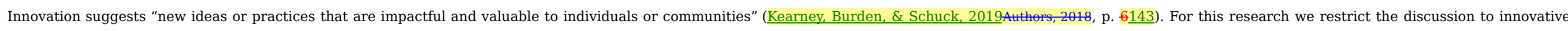

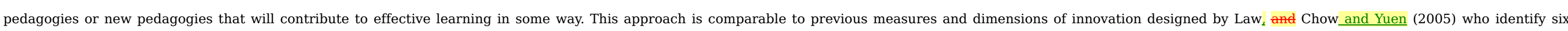

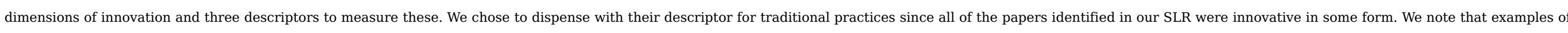

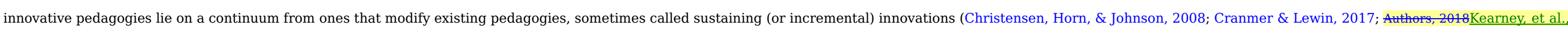

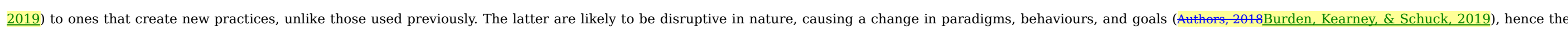
term disruptive (or radical) innovations (Christensen et al., 2008; Cranmer \& Lewin, 2017).

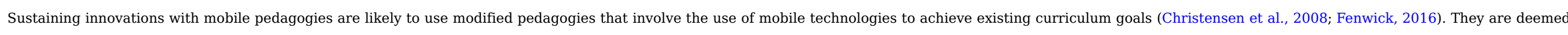

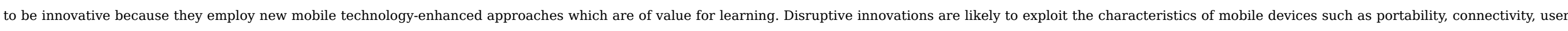

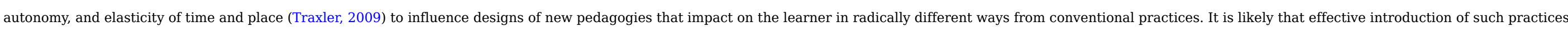

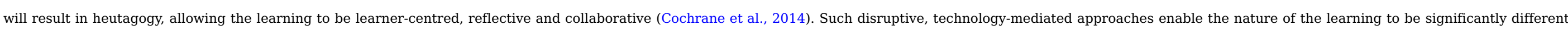

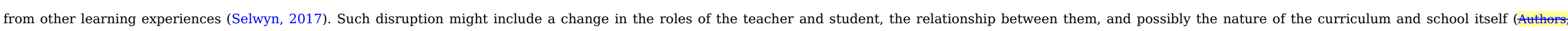
2018Burden, et al., 2019).

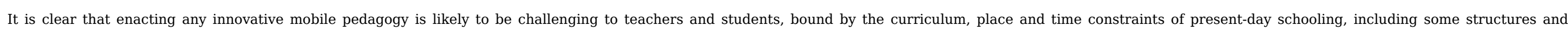

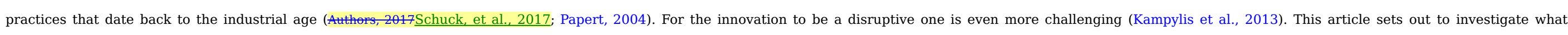

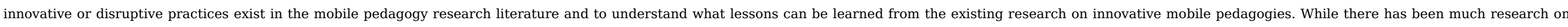




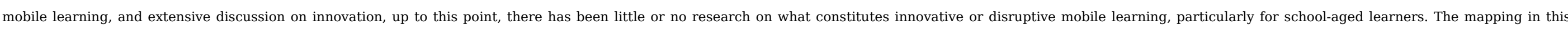
article provides much-needed and original insights into this lacuna.

\section{Research design}

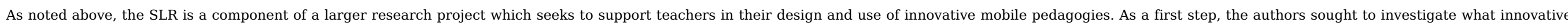
mobile pedagogies might look like. This took the form of an SLR which investigated the following research questions:

The research questions for this SLR are:

1. What do innovative and disruptive mobile pedagogies for school-aged learners look like?

2. To what extent do innovative mobile pedagogies disrupt structures and practices of teaching and learning for school-aged learners?

\subsection{Search strategy}

We took the following steps in order to thoroughly search for the relevant studies:

1. Derived key search terms arising from the Research Questions;

2. Identified possible replacement terms for our key search terms, as used in published literature;

3. Constructed a search string from the resulting terms, connected using Boolean operators;

4. Selected a range of online databases for searching;

5. The string was applied on abstracts;

6. The searches were open for dates from 2010 to 2017;

7. Managed the search findings using an annotation program.

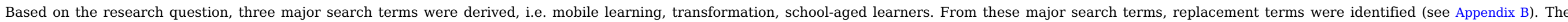
following search string was then used to search on abstracts of relevant papers:

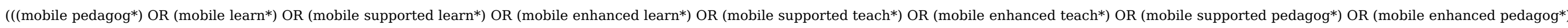

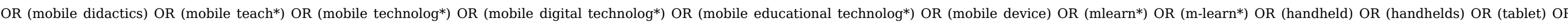

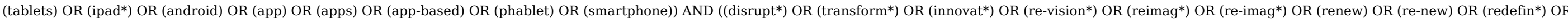

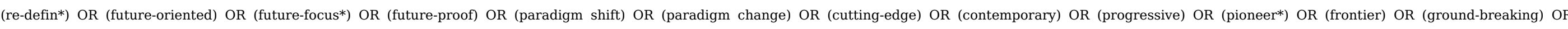

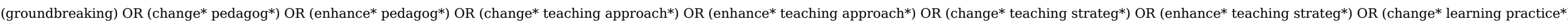

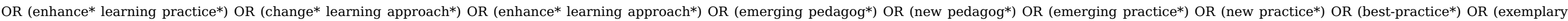

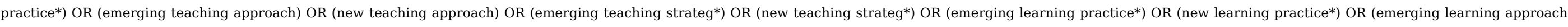

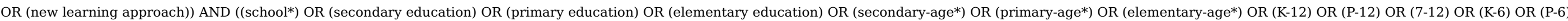
OR (7-10) OR (K12) OR (K6) OR (P12) OR (P6) OR (youth) OR (teen*) OR (adolescen*) OR (child*) OR (tween)))

The string was amended as necessary and applied to different online databases to ensure that relevant studies were not missed. The following databases were selected:

- Education Research Complete (https://www.ebsco.com/products/research-databases/education-research-complete)

- ERIC (https://eric.ed.gov) 
- Gale (https://www.gale.com/databases)

- Informit A + Education (https://www.informit.org/informit-education)

- ProQuest (http://www.proquest.com)

- Sage Journals (http://online.sagepub.com)

- Scopus (https://www.elsevier.com/solutions/scopus)

- Web of Science (https://clarivate.com/products/web-of-science)

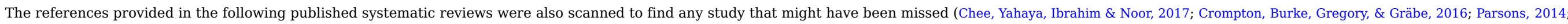
Pereira \& Rodrigues, 2013; Sung, Chang, \& Liu, 2016). Those papers that appeared to be eligible for consideration were treated with the same study selection criteria set for the primary search selection.

\subsection{Study selection}

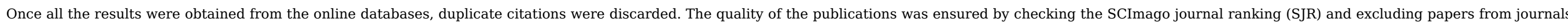

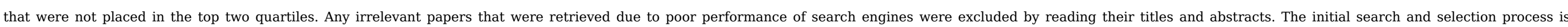
summarised in Table 1.

Table 1 Search and selection summary.

alt-text: Table 1

Digital library

Education Research Complete

ERIC

Gale

Informit A + Education

ProQuest

Sage Journals

Scopus

Web of Science

References from recent reviews

TOTAL

TOTAL when duplicates removed and journal impact factor applied

TOTAL after exclusion due to poor database search performance
Number of articles

108

93

12

99

75

30

215

204

6

842

244

208

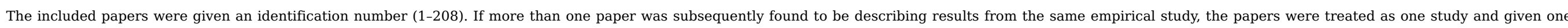
identification number.

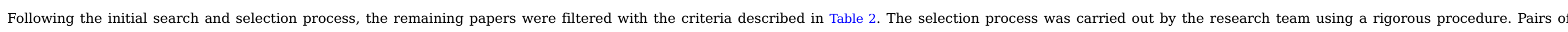

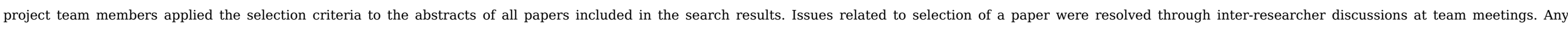
remaining questions were resolved by reading the full text of the paper. Different team members randomly checked among the results to reduce selection bias-(see Table 3 ). 
Table 2 Study selection criteria.

alt-text: Table 2

Inclusion Criteria

\section{Exclusion Criteria}

Published in English

Published from 2010 to 2017

The SCImago journal ranking (SJR) is in the top two quartiles

Targets school-aged learners

Is focused on innovative pedagogies and mobile technologies

Not empirical (book review, opinion, editorial, conceptual work, framework or thesis

Not empirical (book review, opinion, editorial, conceptual work, framework or thesis)

Pedagogy is not innovative

Table 3 (Table 3 should be moved down to under the reference to it.) Alignment of Law et al.'s (2005) six dimensions of innovation with the four factors used in our study.

alt-text: Table 3

Law et al.'s (2005) dimensions of innovation

Alignment to our factors

Intended curriculum goals of the innovative practices

Pedagogical role(s) of the teachers; $\quad$ C

Role(s) of the students; $\quad$ D

Nature and sophistication of the ICT used $\quad$ A

Multidimensional learning outcomes exhibited $\quad$ A

Connectedness of the classroom.

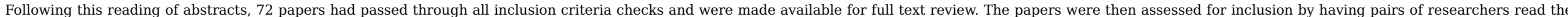
full text to determine whether:

1. Convincing evidence was presented and methodology was rigourous, that is the quality was assessed as high (see section 3.3 below);

2. The paper showed evidence-based benefits to learners (affective, cognitive etc.):

3. Pedagogical strategies/interventions were identified

4. A pedagogical innovation was presented.

If any of these criteria was not met, the paper was excluded. Any issues were resolved through discussions involving the whole team.

\subsection{Study quality assessment and data extractions}

The next step was to ensure the quality of the included papers. We assessed the quality of each paper on following criteria:

1. Publication outlet: The SJR value of the journal was assessed to rank the included articles;

2. Impact: Google scholar or Scopus citation count along with the year of publication was used to assess the impact of the study;

3. Research methodology. Clear research aims, research questions, data collection methodology, data analysis and results.

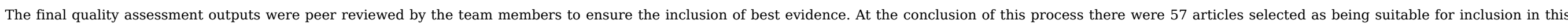
systematic review (see Appendix A for full list of 57 articles) 
1. General attributes: The general attributes included title, year of publication, authors, publication outlet, geographical location (location in which the study was conducted):

2. Context: The context and the details of how the study was implemented;

3. Findings: The information required to answer the research questions, i.e. the evidence presented of innovative pedagogies and benefit to learners.

\subsection{Criteria for innovative studies}

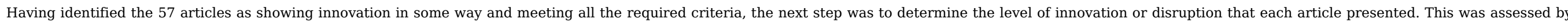
investigating the level of innovation of each of the following factors or elements of learning. These four factors were derived from the discussion of innovation suggested by the literature:

A. The purpose of learning (e.g. the curriculum; learning objectives, etc) and/or the nature of the task/activity and/or the embeddedness of mobile learning;

B. The context of the learning (e.g. the place or time in which learning is undertaken; pedagogical practices; mode);

C. The role of the teacher/educators and their relationship with the students (didactic; involving communities other than school);

D. The role of the learner (agency, passive).

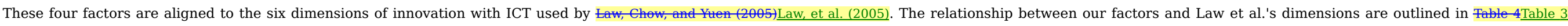
(Insert Table 3 here, not in its current position above.)

\section{Table 4 (Table 4 should be moved down to where it is referenced) Initial scores of individual researchers.}

\section{alt-text: Table 4}

$$
\text { Researchers (Paper id. numbers) }
$$

All 3 researchers (Nine Papers: Nos. 2, 13, 28, 55, 56, 82, 109, 114, 141)

Researcher 1 (16 Papers: Nos. 10, 12, 14, 15, 21, 22, 26, 31, 39, 42, 44, 45, 47, 48, 51, 60)

Researcher 2 (15 Papers: Nos. 63, 76, 78, 79, 86, 88, 89, 90, 92, 93, 97, 101, 102, 110, 119)

Researcher 3 (17 Papers: Nos. 120, 123, 131, 135, 142, 146, 158, 159, 165, 172, 173, 176, 179, 182, 1.3 $183,186,198)$

Overall Averages (All 57 papers)

\begin{tabular}{|l|l|}
\hline Task/activity & \multicolumn{2}{|c|}{ C } \\
\hline 1.8 & 2.1 \\
\hline 1.7 & 1.3 \\
\hline 1.8 & 1.5 \\
\hline 1.3 & 1.5 \\
\hline 1.6 & 1.5 \\
\hline
\end{tabular}

1.5

\section{Context of the learning (e.g.} time/place/space)

\section{Relationship between teacher/student}

2

1.1

1.4

1.3

1.3
Student

agency

2.1

1.1

1.9

1.9

1.7
Total

7.4

5.1

6.5

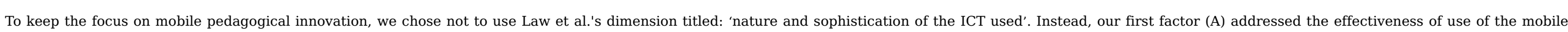

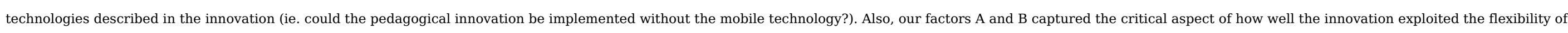
mobile learning contexts.

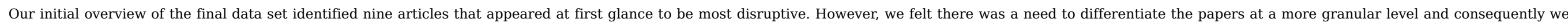

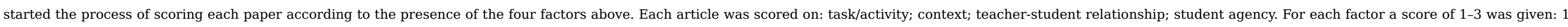

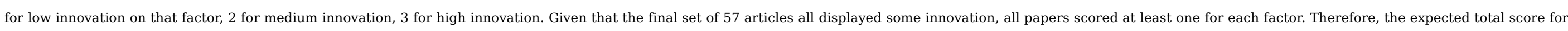
each article across all four factors ranged from 4 to 12. Using these total scores, we were able to classify each paper as follows: Low Innovation: (total score of) 4-6; Medium Innovation: 7-9; High Innovation: 10-12.

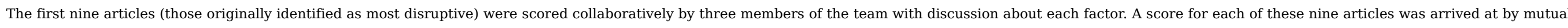

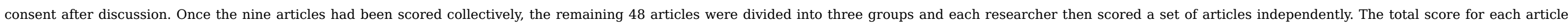
comprised a sum of the scores the article had achieved on each of the four factors. 


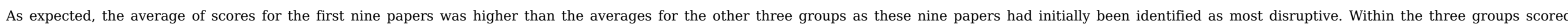

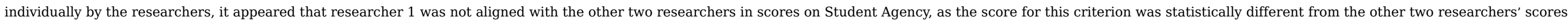

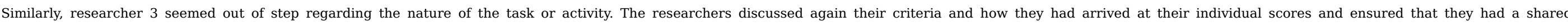

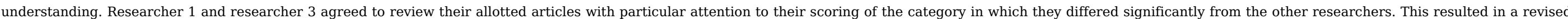
set of scores that were better aligned - see Table 5 .

Table 5 (Table 5 should be in landscape so full table can be read) Final researcher scores on innovation.

alt-text: Table 5

\section{Researchers (Paper id. numbers)}

\begin{tabular}{|c|c|c|c|}
\hline Task/activity & $\begin{array}{c}\text { Context of the learning (e.g. } \\
\text { time/place/space) }\end{array}$ & $\begin{array}{l}\text { Relationship between } \\
\text { teacher/student }\end{array}$ & $\begin{array}{l}\text { Student } \\
\text { agency }\end{array}$ \\
\hline 1.8 & 2.1 & 2 & 2.1 \\
\hline 1.8 & 1.3 & 1.2 & 1.8 \\
\hline 1.8 & 1.5 & 1.4 & 1.9 \\
\hline 1.9 & 1.5 & 1.3 & 1.9 \\
\hline 1.8 & 1.5 & 1.4 & 1.9 \\
\hline
\end{tabular}

All 3 researchers (Nine Papers: Nos. 2, 13, 28, 55, 56, 82, 109, 114, 141)

Researcher 1 (16 Papers: Nos. 10, 12, 14, 15, 21, 22, 26, 31, 39, 42, 44, 45, 47, 48, 51, 60)

Researcher 2 (15 Papers: Nos. 63, 76, 78, 79, 86, 88, 89, 90, 92, 93, 97, 101, 102, 110, 119)

Researcher 3 (17 Papers: Nos. 120, 123, 131, 135, 142, 146, 158, 159, 165, 172, 173, 176, 179, 182, 1.9 $183,186,198)$

Overall Averages (All 57 papers)

\section{Findings}

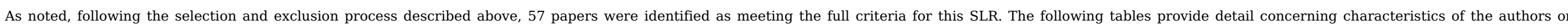
research studies reported.

\subsection{Details of studies}

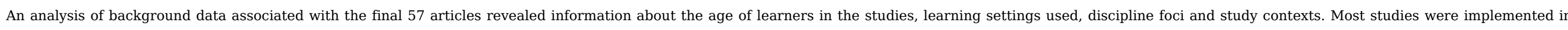
South-east Asia and Europe, as shown in Table 6 below.

Table 6 Geographical distribution of papers.

\section{alt-text: Table 6}

Region

Number of papers

South-east Asia (Taiwan (14), Singapore (8), South Korea, Hong Kong)

5

Europe (Italy, Spain, France, Germany, Ireland, Sweden, The Netherlands, Cyprus, UK)

North America (USA (6), Canada)

Australia

Middle East (Israel)

South America (Chile, Trinidad and Tobago)

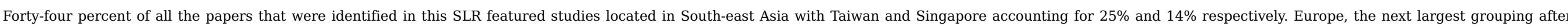




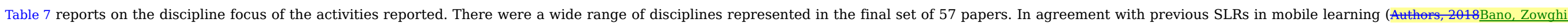

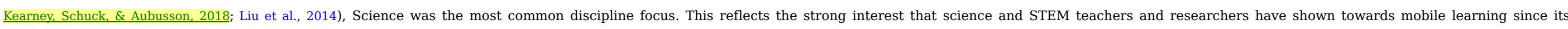
inception (secte 8 ).

Table 7 Discipline focus of papers.

alt-text: Table 7

\begin{tabular}{|c|c|}
\hline Discipline focus & Number of papers \\
\hline Science & 20 \\
\hline Social Science & 9 \\
\hline Languages & 4 \\
\hline Literacy & 4 \\
\hline Maths & 4 \\
\hline Visual Arts & 4 \\
\hline Generic (e.g. focus on reflective practices) & 4 \\
\hline Geography & 2 \\
\hline Cross-discipline (range of subjects) & 2 \\
\hline Health/Physical Education (PE) & 2 \\
\hline English & 1 \\
\hline Environmental studies & 1 \\
\hline
\end{tabular}

Table 8 Background data on learners' age groups.

alt-text: Table 8

\begin{tabular}{|c|c|c|}
\hline & Age of learners & Number of papers \\
\hline $6-12$ & & 31 \\
\hline $13-18$ & & 22 \\
\hline $6-18$ & & 3 \\
\hline Life-long & & 1 \\
\hline
\end{tabular}

The majority of studies focused on upper primary/elementary aged learners, followed by secondary school students, particularly middle school aged learners. See Table 8 .

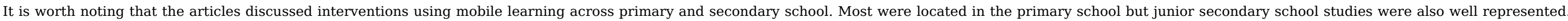
Studies that went across school levels were less common, but this may have been a result of the emphasis on 'school-aged' in the search strings.

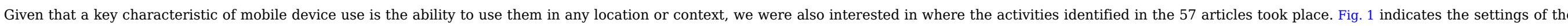

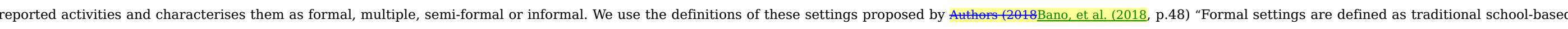

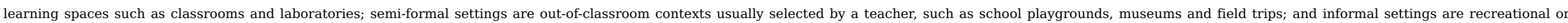




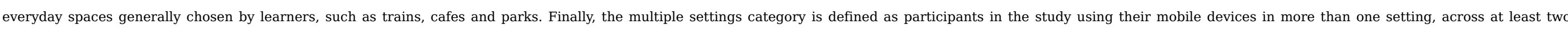
(physical) learning spaces." Overall, $45 \%$ of papers described use of formal settings, $13 \%$ semi-formal settings, $5 \%$ used informal; settings and $37 \%$ used multiple settings, as shown in Fig. 1.

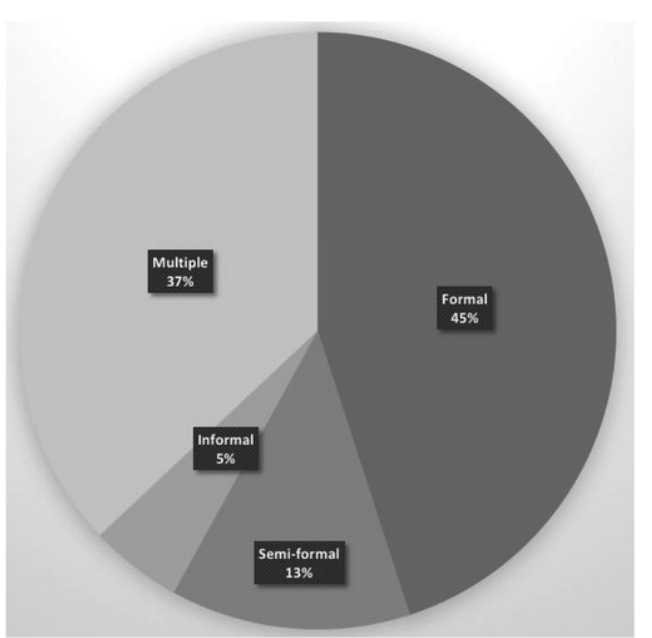

Fig. 1 Contexts of study activities.

alt-text: Fig. 1

It is worth noting that although mobile learning has a major characteristic of portability, the majority of articles described innovations that took place in the classroom or school grounds, as shown in Fig. 2.

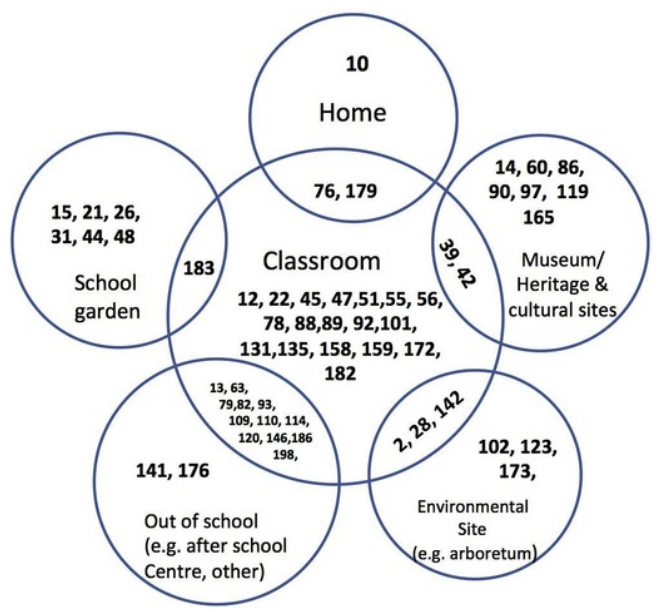

Fig. 2 Contexts of activities from 57 SLR articles.

alt-text: Fig. 2

\subsection{Extent of disruption}

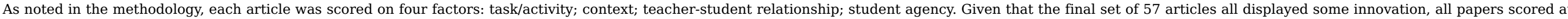

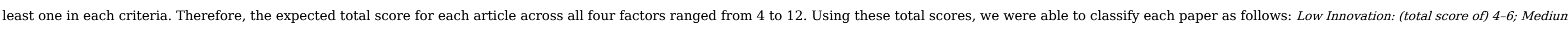
Innovation: 7-9; High Innovation: 10-12. 


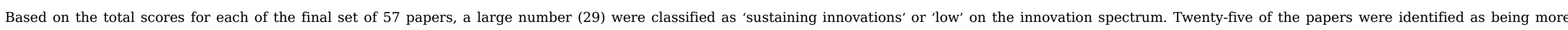
disruptive innovations (labelled as medium on the innovation spectrum) and just three were classified as radically disruptive innovations (high on the innovation spectrum), as shown in Fig. 3 below.

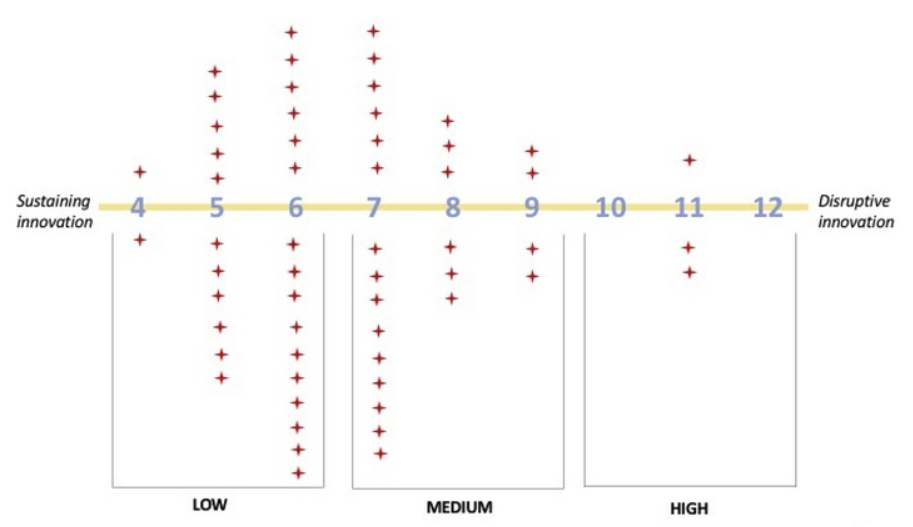

Fig. 3 Innovation Continuum - breakdown of all 57 papers according to level of innovation. alt-text: Fig. 3

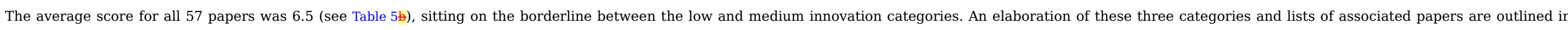
Table 9.

Table 9 (please ensure the whole table fits on the page) Waypoints along the innovation spectrum.

\section{alt-text: Table 9 \\ Low (29 papers) Sustaining innovation}

The innovation:

- is adapted from existing practices or approaches to make them more

effective or efficient, but not to radically change them;

- adapts existing pedagogies, practices or structures to make them more efficient/effective Papers: $12,14,15,21,26,31,42,44,45,48,55$
$56,60,63,76,78,79,88,89,90,92,131,135$ $158,159,165,172,182,183$

$$
\text { Medium (25 papers) }
$$

The innovation modified or added something new but this did not in itself fundamentally challenge or alter the underlying approaches, purposes, structures or practices

Papers: 10, 13, 22, 39, 47, 51, 82, 86, 93, 97, 101, 102, 109 $110,114,119,120,123,142,146,173,176,179,186,198$
High (3 papers) Disruptive innovation

\section{The innovation:}

- changes the existing paradigm. It creates new educational purposes or processes and challenges and fundamentally alters existing approaches and practices such as the relationship between teachers and students or the nature of the curriculum

- enables learning to occur in ways and contexts that could not occur without a mobile device.

Papers: 2, 28, 141

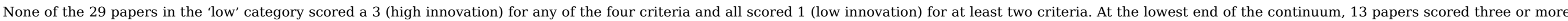
1 's in the four categories, and two papers scored all 1 's.

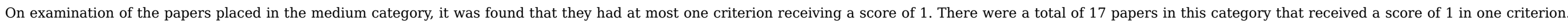

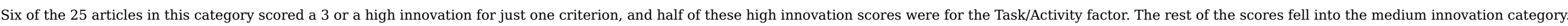




\section{Discussion}

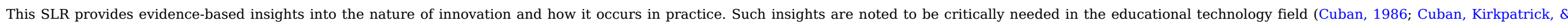

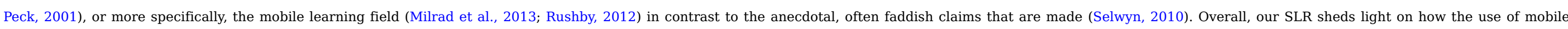

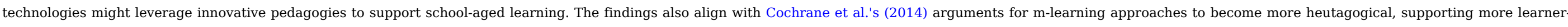
centred, reflective and collaborative processes.

\subsection{The innovation continuum}

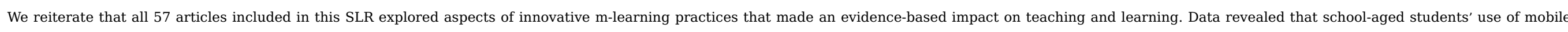

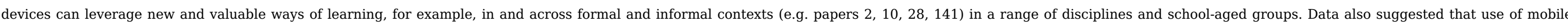

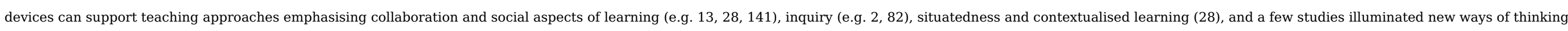
about teacher roles (e.g. 2, 13, 28, 102) and student agency $(2,13,28,102)$ that might disrupt traditional approaches.

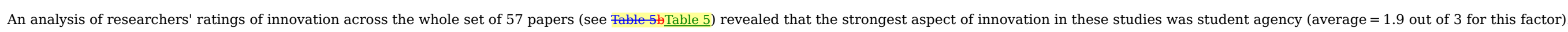

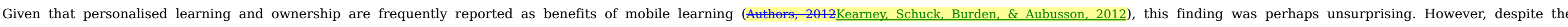

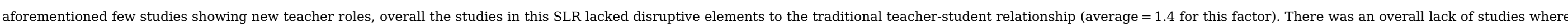

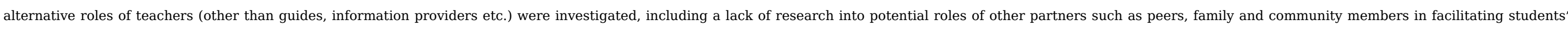
learning across a range of contexts.

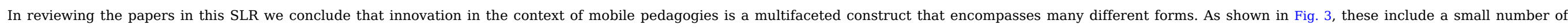

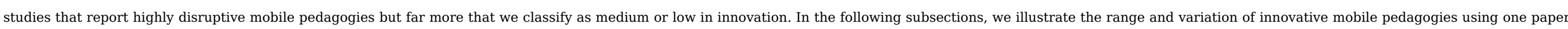

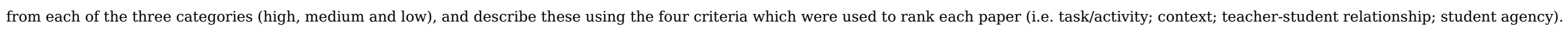

\subsubsection{Radical disruptions: high on the innovation spectrum}

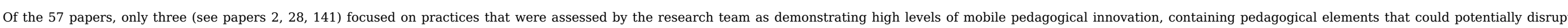
traditional practices (see Table 9 above). All three papers report how students undertook tasks and activities that would have been demanding or even impossible without mobile technologies.

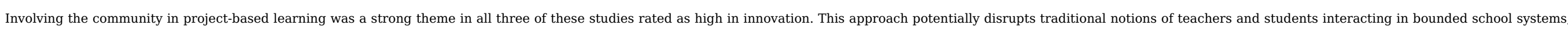

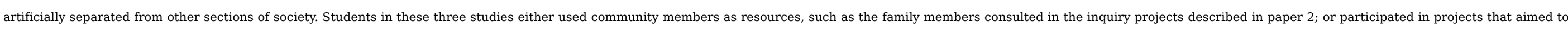

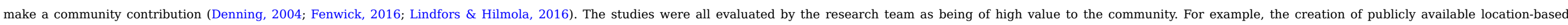
interactive learning objects (LILOs) in paper 28, and collection of data in the health promotion project in paper 141, evidently made valuable contributions to local virtual and physical communities.

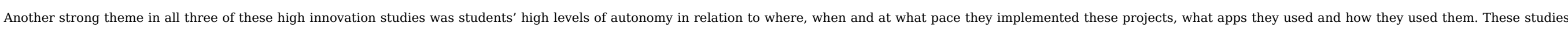

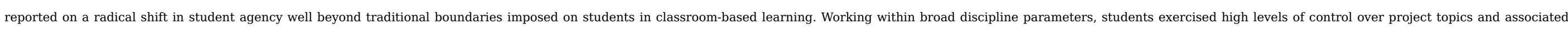
learning objectives, and enjoyed high degrees of agency in the design process of their projects, as they co-designed apps (paper 141) and LILOs (paper 28).

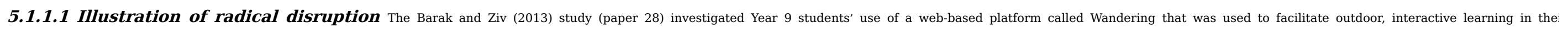

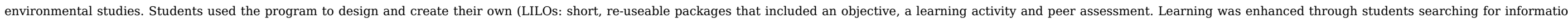
creating their LILO, and then sharing it with the community using social media. Findings indicated high motivation among students not only for completing their school assignment, but also for contributing to the community.

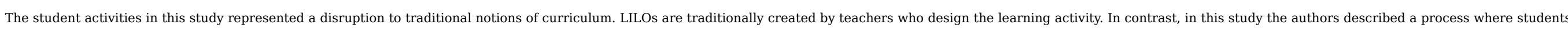

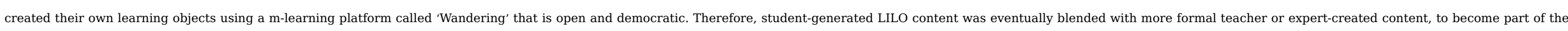




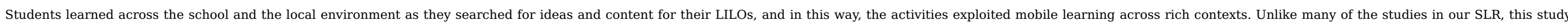

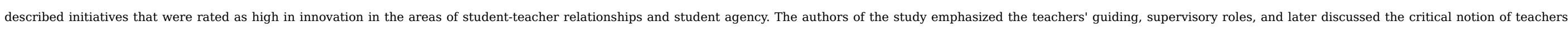
'releasing control' to encourage students' independent learning, allowing them "to explore, make mistakes, and learn from them; all this, while they are out of the classrooms walls" (p. 169).

\subsubsection{Medium innovations: medium on the innovation spectrum}

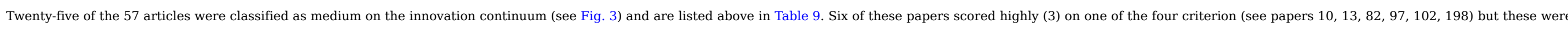

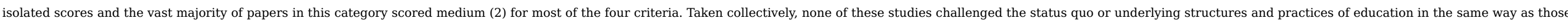
described as 'disruptive innovations' above. The paper below is representative of those described as 'medium innovations'.

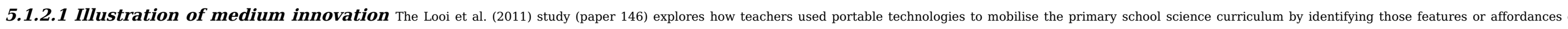

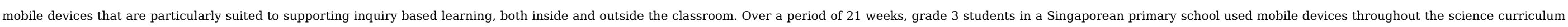

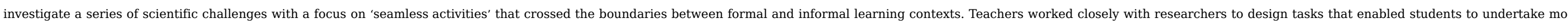

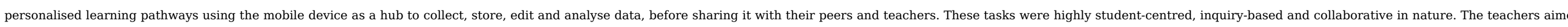

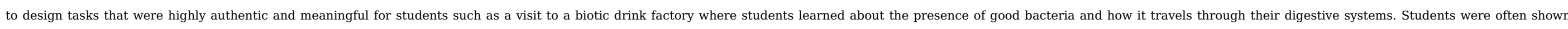

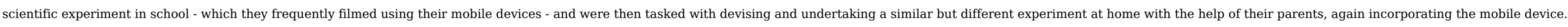

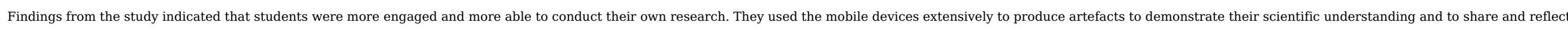

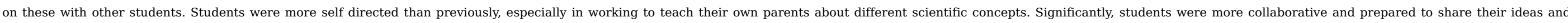
reflections with peers which altered the culture of science lessons.

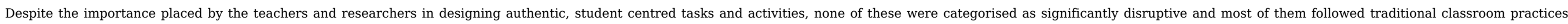

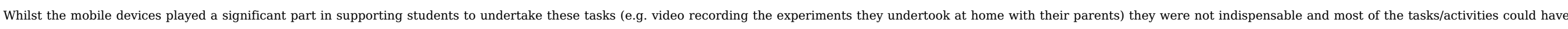

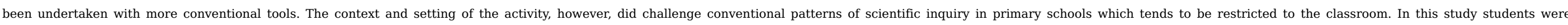

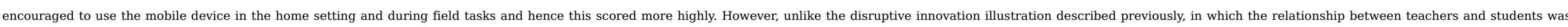

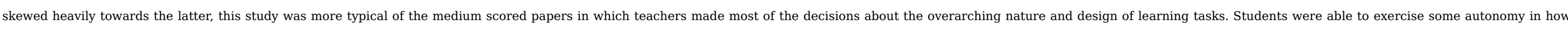

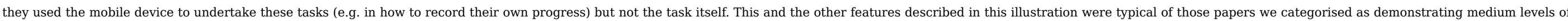
innovation.

\subsubsection{Sustaining innovations: low on the innovation spectrum}

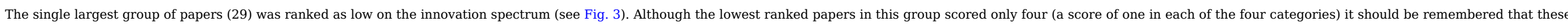

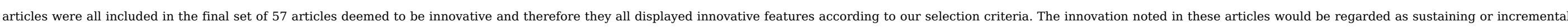

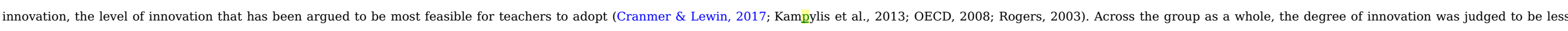

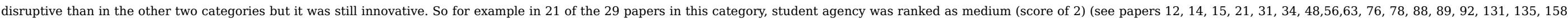

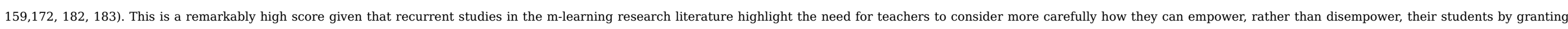
them more opportunities to use their mobile device to exercise greater autonomy and make more choices (authersearnev, Burden, \& Rai, 2015). This point is highlighted in the illustrative paper below.

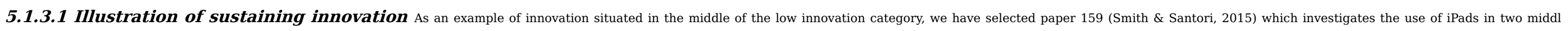

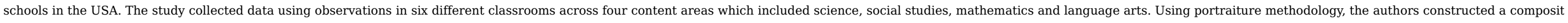

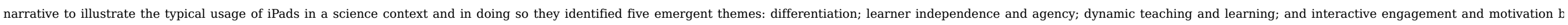

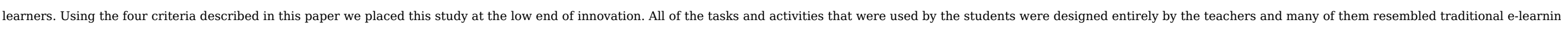




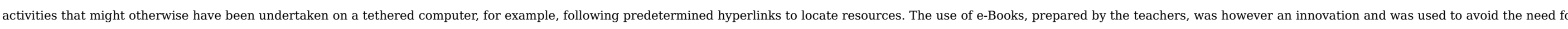

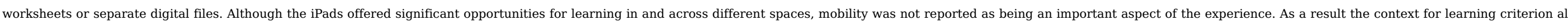

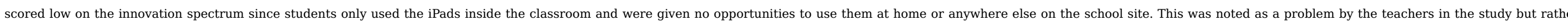

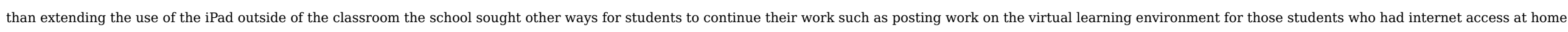

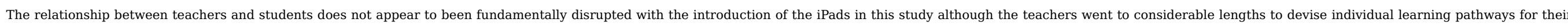

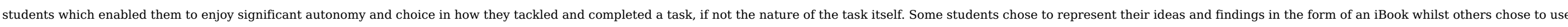
more concrete approaches such as LEGO. Therefore although the teacher/student relationship was deemed to be fairly traditional, the score for student agency was rated as medium.

\subsection{Feasible mobile pedagogical innovations for school-aged learners}

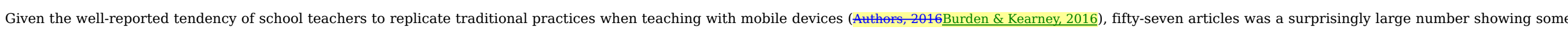

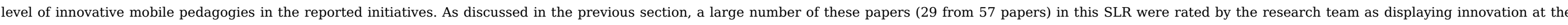

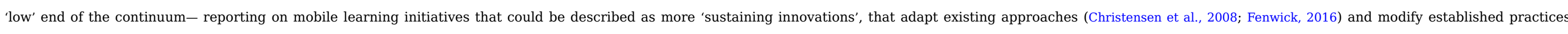

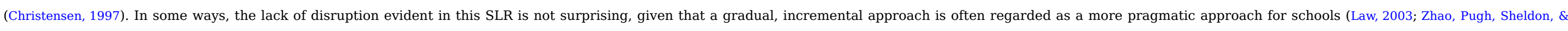

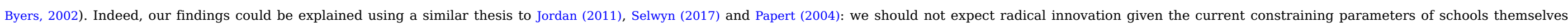
including an over-emphasis on high stakes testing, rigid timetables and constrained learning spaces and out-moded curriculum content (in some institutions, akin to 19th century models of schooling).

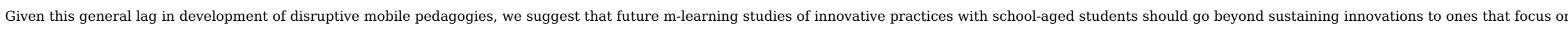

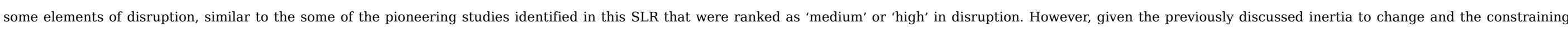

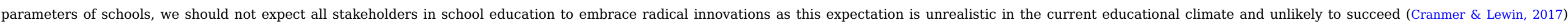

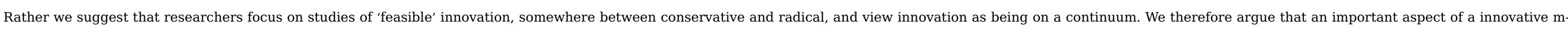
learning practice for school-aged learners is its feasibility and likelihood to succeed and be scalable.

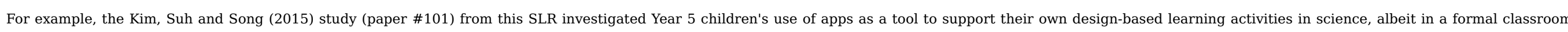

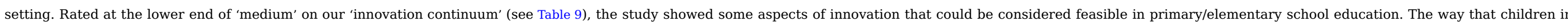

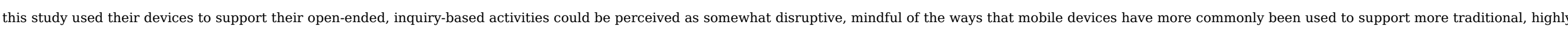

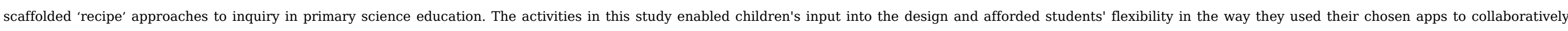

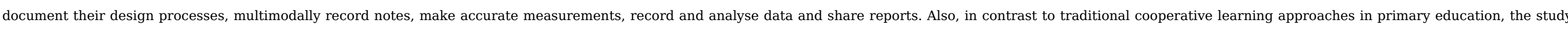

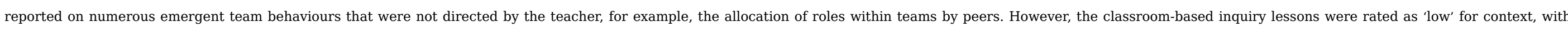

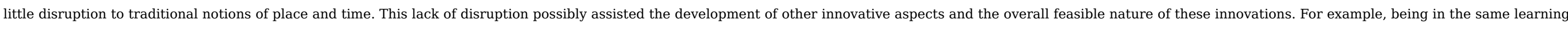
space (at the same time) as their peers and the teacher might have had a positive benefit on some of the inter-team and student-teacher interactions.

\section{Limitations}

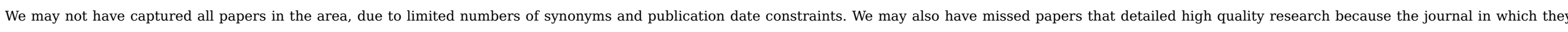

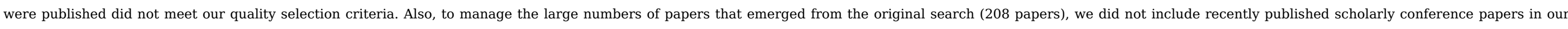
search. However, the 57 papers in our final selection provided a comprehensive and trustworthy set of data on innovation in mobile learning.

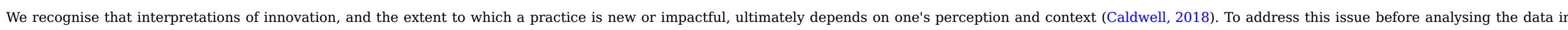

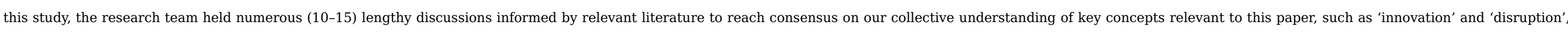

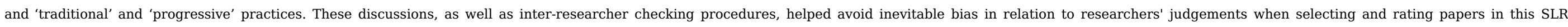

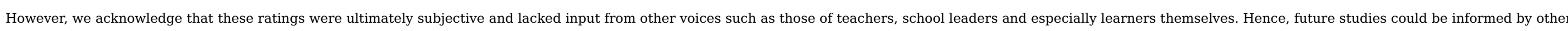




\section{Future studies}

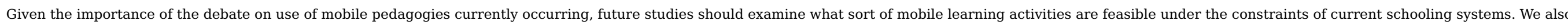
encourage further studies on what other 'feasible innovative mobile pedagogies' might look like, across a range of contexts.

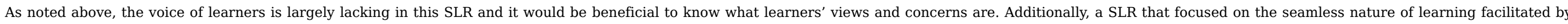

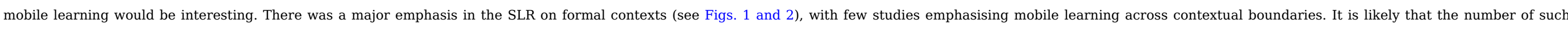
studies will increase in the future and a SLR that captures such activities would provide rich information on an important affordance of mobile learning.

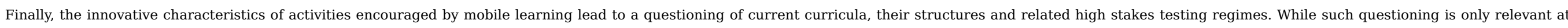

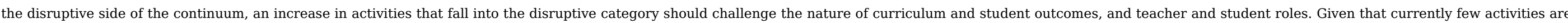

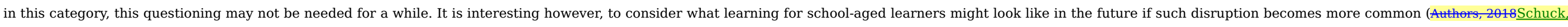
et al., 2018).

\section{Conclusion}

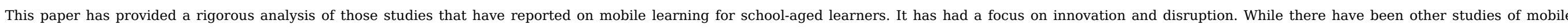

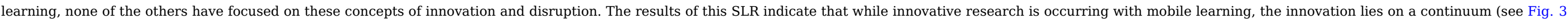

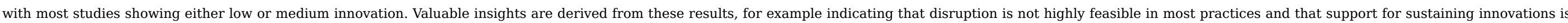

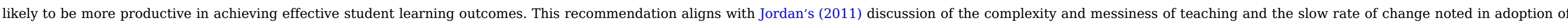
educational technologies for teaching and learning. These insights are useful for policy-makers, researchers, curriculum developers and education stakeholders generally.

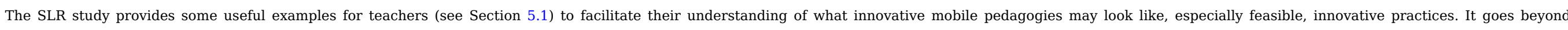

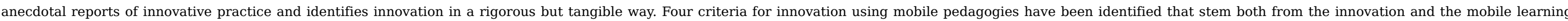

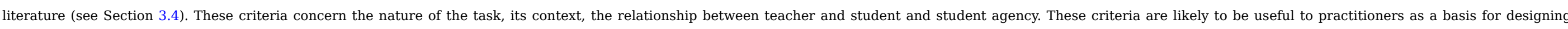

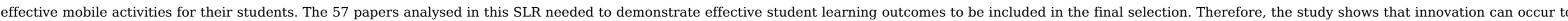
varying degrees across the four criteria to result in effective student learning outcomes and engagement.

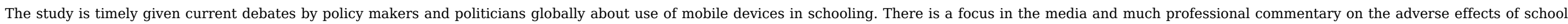

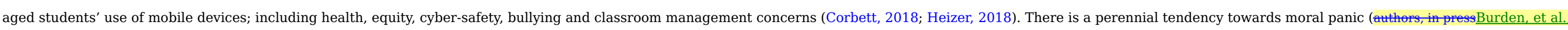

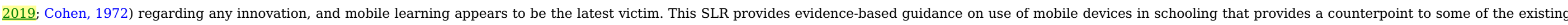
concerns.

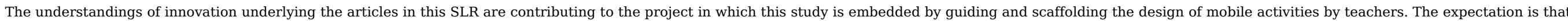
this analysis will also contribute more broadly to the enactment of innovative teaching and learning using mobile devices.

\section{Appendix A. Supplementary data}

Supplementary data to this article can be found online at https://doi.org/10.1016/j.compedu.2019.04.008.

\section{Appendix A. List of 57 articles from final inclusion in SLR (with paper \#'s from original 208 papers)}

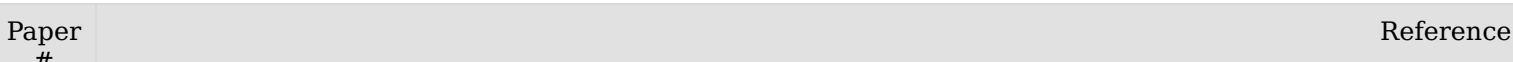


Pacific Education Researcher, 26(5), 305-316. https://doi.org/10.1007/s40299-017-0350-5

10 Kervin, L. (2016). Powerful and playful literacy learning with digital technologies. Australian Journal of Language and Literacy, The, $39(1)$, 64-73.

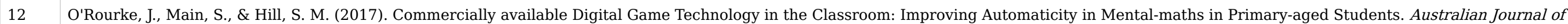
Teacher Education, 42(10), 4

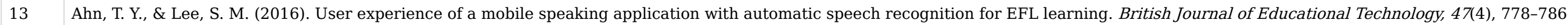
https://doi.org/10.1111/bjet.12354

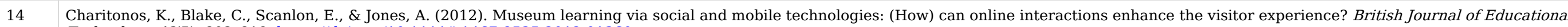
Technology, 43(5), 802-819. https://doi.org/10.1111/j.1467-8535.2012.01360.x

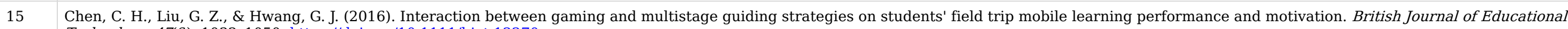
Technology, 47(6), 1032-1050. https://doi.org/10.1111/bjet.12270

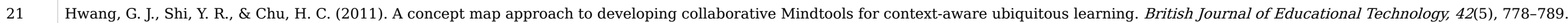
https://doi.org/10.1111/j.1467-8535.2010.01102.x

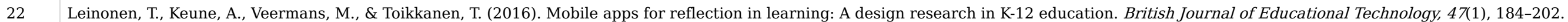
https://doi.org/10.1111/bjet.12224

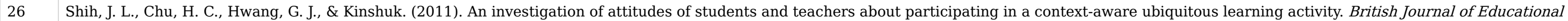
Technology, 42(3), 373-394. https://doi.org/10.1111/j.1467-8535.2009.01020.x

28 Barak, M., \& Ziv, S. (2013). Wandering: A Web-based platform for the creation of location-based interactive learning objects. Computers \& Education, 62, 159-170. https://doi.org/10.1016/j.compedu.2012.10.015

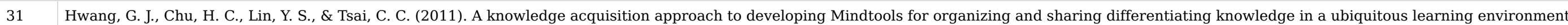
Computers \& Education, 57(1), 1368-1377. https://doi.org/10.1016/j.compedu.2010.12.013

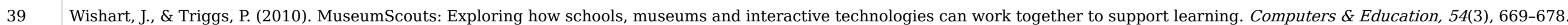
https://doi.org/10.1016/j.compedu.2009.08.034

42 Chen, C. C., \& Huang, T. C. (2012). Learning in a u-Museum: Developing a context-aware ubiquitous learning environment. Computers and Education, 59(3), 873-883. https://doi.org/10.1016/j.compedu.2012.04.003

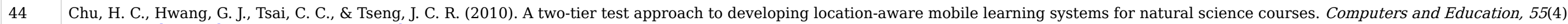
1618-1627. https://doi.org/10.1016/j.compedu.2010.07.004

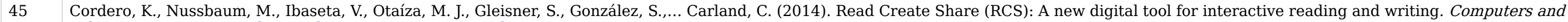
Education, 82, 486-496. https://doi.org/10.1016/j.compedu.2014.12.006

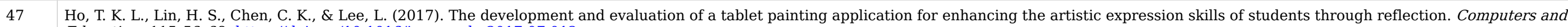
Education, 115, 56-68. https://doi.org/10.1016/j.compedu.2017.07.012

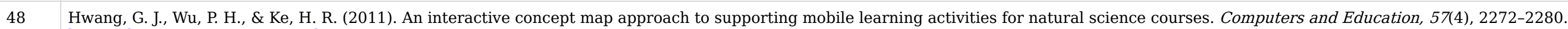
https://doi.org/10.1016/j.compedu.2011.06.011

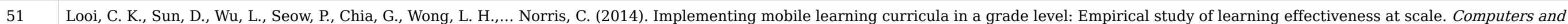
Education, 77, 101-115. https://doi.org/10.1016/j.compedu.2014.04.011

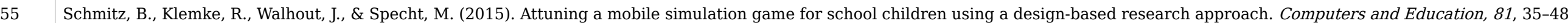
https://doi.org/10.1016/j.compedu.2014.09.001

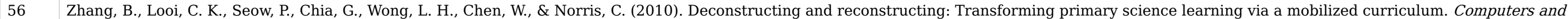
Education, 55(4), 1504-1523. https://doi.org/10.1016/j.compedu.2010.06.016

60 Melero, J., Hernández-Leo, D., \& Manatunga, K. (2015). Group-based mobile learning: Do group size and sharing mobile devices matter? Computers in Human Behavior, 44, 377-385. https://doi.org/10.1016/j.chb.2014.11.078

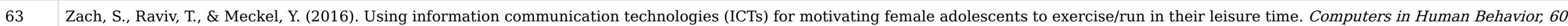
593-601. https://doi.org/10.1016/j.chb.2016.02.096

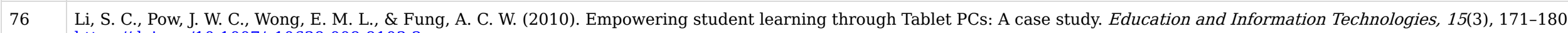
https://doi.org/10.1007/s10639-009-9103-2 
Sanchez, E., Young, S., \& Jouneau-Sion, C. (2017). Classcraft: from gamification to ludicization of classroom management. Education and Information Technologies, 22(2), 497-513. https://doi.org/10.1007/s10639-016-9489-6

79 Tortorella, R. A. W., \& Graf, S. (2017). Considering learning styles and context-awareness for mobile adaptive learning. Education and Information Technologies, 22(1), 297-315. https://doi.org/10.1007/s10639-015-9445-x

82 Bower, M., Howe, C., McCredie, N., Robinson, A., \& Grover, D. (2014). Augmented Reality in Education--Cases, Places and Potentials. Educational Media International, 51(1), 1-15.

86 Chen, C. P., Shih, J. L., \& Ma, Y. C. (2014). Using Instructional Pervasive Game for School Children's Cultural Learning. Educational Technology \& Society, 17(2), 169-182.

88 Kim, H. J., Park, J. H., Yoo, S., \& Kim, H. (2016). Fostering Creativity in Tablet-Based Interactive Classrooms. Educational Technology \& Society, 19(3), 207-220.

Looi, C. K., \& Wong, L. H. (2014). Implementing Mobile Learning Curricula in Schools: A Programme of Research from Innovation to Scaling. Educational Technology \& Society, $17(2), 72-84$.

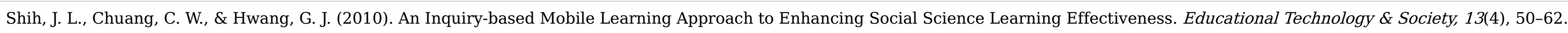

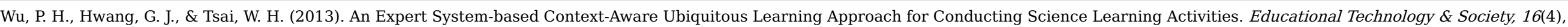
217-230.

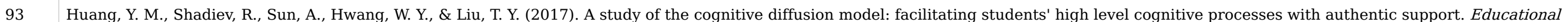
Technology Research and Development, 65(3), 505-531. https://doi.org/10.1007/s11423-016-9475-0

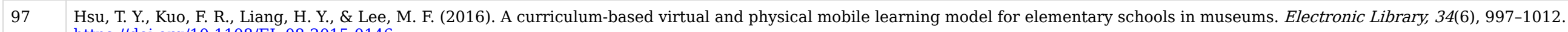
https://doi.org/10.1108/EL-08-2015-0146

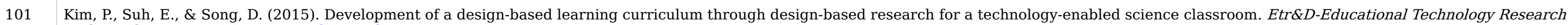
and Development, 63(4), 575-602. https://doi.org/10.1007/s11423-015-9376-7

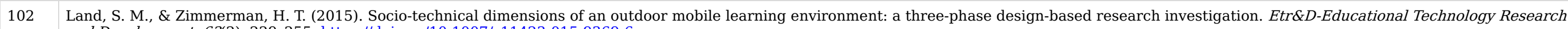
and Development, 63(2), 229-255. https://doi.org/10.1007/s11423-015-9369-6

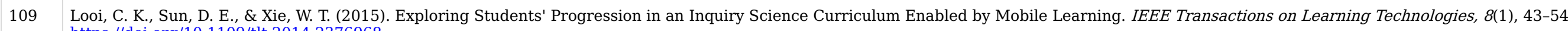
https://doi.org/10.1109/tlt.2014.2376968

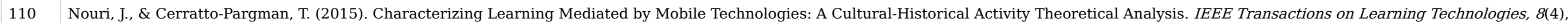
357-366. (Paper \#110)

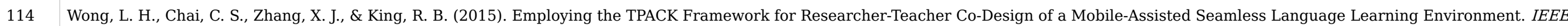
Transactions on Learning Technologies, 8(1), 31-42. https://doi.org/10.1109/tlt.2014.2354038

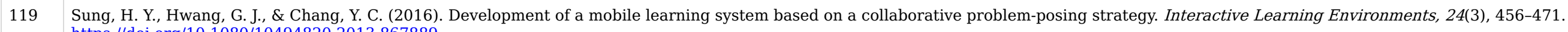
https://doi.org/10.1080/10494820.2013.867889

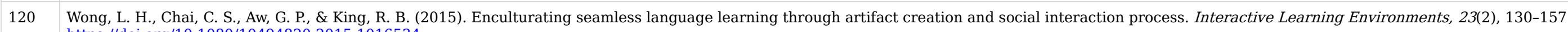
https://doi.org/10.1080/10494820.2015.1016534

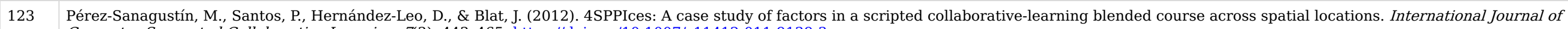
Computer-Supported Collaborative Learning, 7(3), 443-465. https://doi.org/10.1007/s11412-011-9139-3

131 Kalloo, V., \& Mohan, P. (2011). An Investigation Into Mobile Learning for High School Mathematics. International Journal of Mobile and Blended Learning, 3(3), 59-76. https://doi.org/10.4018/jmbl.2011070105 (Paper \#131)

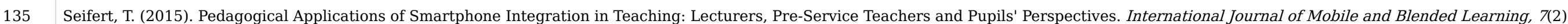
1-16. https://doi.org/10.4018/ijmbl.2015040101

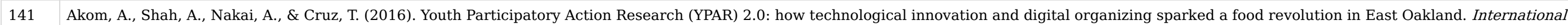
Journal of Qualitative Studies in Education, 29(10), 1287-1307. https://doi.org/10.1080/09518398.2016.1201609

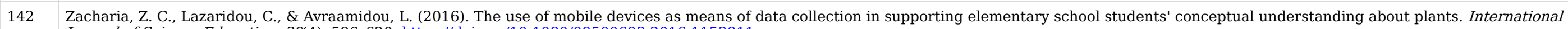
Journal of Science Education, 38(4), 596-620. https://doi.org/10.1080/09500693.2016.1153811

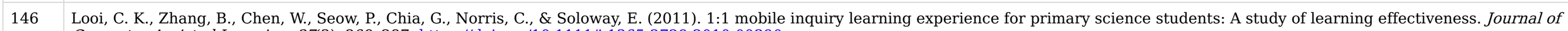
Computer Assisted Learning, 27(3), 269-287. https://doi.org/10.1111/j.1365-2729.2010.00390.x

Ifenthaler, D., \& Schweinbenz, V. (2016). Students' Acceptance of Tablet PCs in the Classroom. Journal of Research on Technology in Education, 48(4), 306-321. 
https://doi.org/10.1080/15391523.2016.1215172

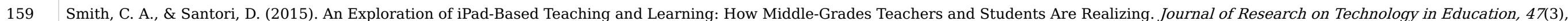
173-185. https://doi.org/10.1080/15391523.2015.1047700

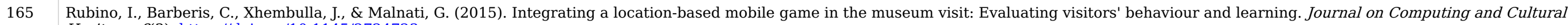
Heritage, 8(3). https://doi.org/10.1145/2724723

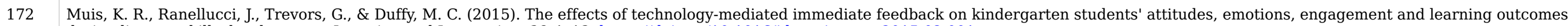
during literacy skills development. Learning and Instruction, 38, 1-13. https://doi.org/10.1016/j.learninstruc.2015.02.001

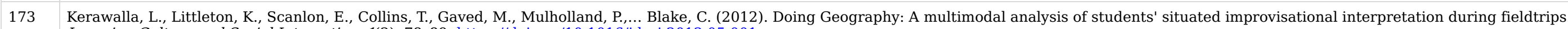
Learning Culture and Social Interaction, 1(2), 78-89. https://doi.org/10.1016/j.lcsi.2012.05.001

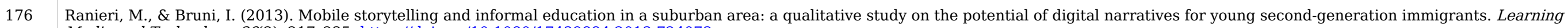
Media and Technology, 38(2), 217-235. https://doi.org/10.1080/17439884.2013.724073

179 Kervin, L., \& Mantei, J. (2016). Digital writing practices: a close look at one grade three author. Literacy, 50(3), 133-140. https://doi.org/10.1111/lit.12084

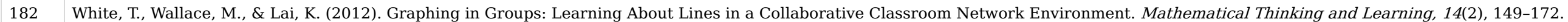
https://doi.org/10.1080/10986065.2012.656363

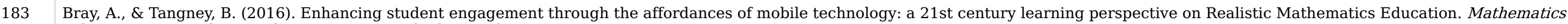
Education Research Journal, 28(1), 173-197. doi:https://doi.org/10.1007/s13394-015-0158-7 (

186 Kucirkova, N., \& Littleton, K. (2017). Developing personalised education for personal mobile technologies with the pluralisation agenda. Oxford Review of Education, 43(3), 276-288. https://doi.org/10.1080/03054985.2017.1305046

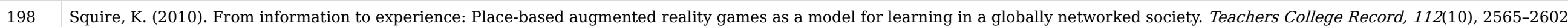

\section{Appendix B. Synonyms and alternatives terms for major search terms}

\begin{tabular}{|c|c|c|}
\hline Mobile learning & Transformation & School-aged learners \\
\hline $\begin{array}{l}\text { mobile pedagog* (mobile pedagogies, } \\
\text { mobile pedagogy) }\end{array}$ & $\begin{array}{l}\text { disrupt* (Disruptive technologies, Disruptive pedagogy, Disruptive approaches, Disruptive } \\
\text { strategies, Disruptive teaching approaches) }\end{array}$ & $\begin{array}{l}\text { school* (schooling, high school, middle school, primary school, } \\
\text { after-school, school student/s }\end{array}$ \\
\hline $\begin{array}{l}\text { mobile learn* (mobile learning, mobile } \\
\text { learning technology) }\end{array}$ & transform* (transformative) & school pupil/s, school learner/s) \\
\hline mobile supported learn* & innovat* (radical innovation & secondary education \\
\hline mobile enhanced learn* & innovative approach* & primary education \\
\hline mobile supported teach* & innovative strateg* & elementary education \\
\hline mobile enhanced teach* & innovative pedagog* & secondary-age* \\
\hline mobile supported pedagog* & incremental/radical innovation & primary-age* \\
\hline mobile enhanced pedagog* & pedagogical innovation, innovative technologies) & elementary-age* \\
\hline mobile didactics & re-vision* & $\mathrm{K}-12$ \\
\hline mobile teach* & reimag* or re-imag & $\mathrm{P}-12$ \\
\hline $\begin{array}{l}\text { mobile technolog* (mobile technology } \\
\text { enhanced learning }\end{array}$ & renew or re-new & $7-12$ \\
\hline mobile technology-based learning & redefin* or re-defin* & $\begin{array}{l}\text { K-6 } \\
\mathrm{P}-6\end{array}$ \\
\hline mobile technology-mediated learning & future-oriented & $7-10$ \\
\hline mobile technology-supported learning & future-focus* & K12 \\
\hline
\end{tabular}




\begin{tabular}{|c|c|c|}
\hline mobile technology integrated learning & future-proof & K6 \\
\hline mobile technology integration & paradigm shift & P12 \\
\hline mobile technology enhanced teaching & paradigm change & P6 \\
\hline mobile technology-based teaching & cutting-edge & youth \\
\hline mobile technology-supported teaching) & contemporary & teen* \\
\hline $\begin{array}{l}\text { mobile digital technolog* } \\
\text { mobile educational technolog* }\end{array}$ & progressive & adolescen* \\
\hline mobile device & pioneer* & child* \\
\hline mLearn* (mlearn, mlearning, mlearner $>>$ ) & frontier & tween \\
\hline m-learn* (m-Learn, m-learning $>>$ ) & ground-breaking & \\
\hline handheld, handhelds & groundbreaking & \\
\hline Tablet, tablets & change* pedagog* & \\
\hline iPad ipads & enhance* pedagog* & \\
\hline android & change* teaching approach* & \\
\hline app & enhance* teaching approach* & \\
\hline apps & change* teaching strateg* & \\
\hline app-based & enhance* teaching strateg* & \\
\hline phablet & change* learning practice* & \\
\hline \multirow[t]{17}{*}{ smartphone } & enhance* learning practice* & \\
\hline & change* learning approach* & \\
\hline & enhance* learning approach* & \\
\hline & emerging pedagog* & \\
\hline & new pedagog* & \\
\hline & emerging practice* & \\
\hline & new practice* & \\
\hline & best-practice* & \\
\hline & exemplary-practice* & \\
\hline & emerging teaching approach & \\
\hline & new teaching approach & \\
\hline & emerging teaching strateg* & \\
\hline & new teaching strateg* & \\
\hline & emerging learning practice* & \\
\hline & new learning practice* & \\
\hline & emerging learning approach & \\
\hline & new learning approach & \\
\hline
\end{tabular}




\section{References}

Authors (2010) Details withheld for blind reviow

Authors (2012). Details withheld for blind review.

Authors (2016) Details withheld for blind reviow.

Authors (2017). Details withheld for blind review.

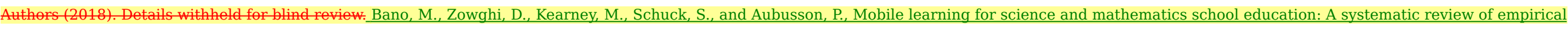
evidence, Computers \& Education, 121, 2018, 30-58

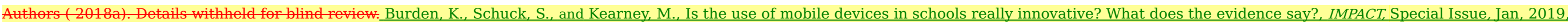

https://impact.chartered.college/article/mobile-devices-schools-really-innovative-what-does-evidence-say/

Authors (2018b). Details withheld for blind review.Burden, K., and Kearney, M., Future scenarios for mobile science learning, Research in Science Education, 46 (2), 2016, 287-308.

Authors (in press) Details theld for blind revien Burden, K., Conceptualising teachers' professional learning with Web 2.0, Campus-Wide Information Systems, 27 (3), 2010, 148-161

https://doi.org/10.1108/10650741011054456.

Caldwell H., Mobile technologies as a catalyst for pedagogic innovation within teacher education, International Journal of Mobile and Blended Learning 10 (2), $2018,50-65$.

Chee K.N., Yahaya N., Ibrahim N.H. and Noor Hassan M., Review of mobile learning trends 2010-2015: A meta-analysis, Educational Technology \& Society 20 (2), 2017, 113-126.

Chen M., Yu S.Q. and Chiang F.K., A dynamic ubiquitous learning resource model with context and its effects on ubiquitous learning, Interactive Learning Environments 25 (1), 2017, 127-141

https://doi.org/10.1080/10494820.2016.1143846.

Christensen C.M., The innovator's dilemma: When new technologies cause great firms to fail (Rev. ed.), 1997, Harvard Business School Press; Boston, MA.

Christensen C.M., Horn M.B. and Johnson C.W., Disrupting class: How disruptive innovation will change the way the world learns, 2008, McGraw-Hill; New York, NY.

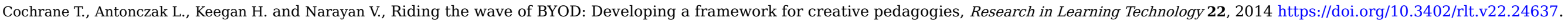

Cohen S., Folk devils and moral panics, 1972, MacGibbon and Kee Ltd; London, UK.

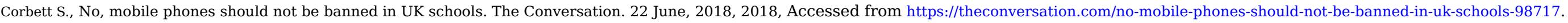

Cranmer S. and Lewin C., iTEC: conceptualising, realising and recognising pedagogical and technological innovation in European classrooms, Technology, Pedagogy and Education 2017,

https://doi.org/10.1080/1475939X.2017.1299791.

Crompton H., Burke D., Gregory K.H. and Gräbe C., The use of mobile learning in science: A systematic review, Journal of Science Education and Technology 25 (2), 2016, 149-160.

Cuban L., Teachers and machines. Classroom use of technology since 1920, 1986, Teachers College Press; New York.

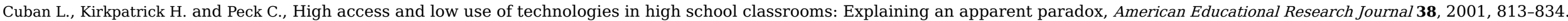

Denning P., The social life of innovation, Communications of the ACM 4 (4), 2004, 15-19.

Fenwick T., Wanted: The innovative professional, In: Fenwick T., (Ed), Professional responsibility and professionalism: A sociomaterial examination, 2016, Routledge; London, 77-92.

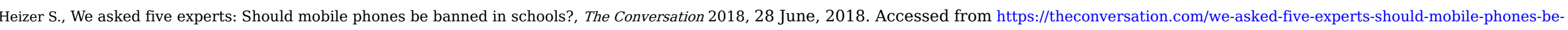


banned-in-schools-98708.

Joan D.R., A study on mobile learning as a learning style in modern research practice, i-Manager's Journal on School Educational Technology 8 (4), $2013,29-37$.

Jordan K., Framing ICT, teachers and learners in Australian school education ICT policy, Australian Educational Researcher 38, 2011, 417-431, https://doi.org/10.1007/s13384-011-0038-4.

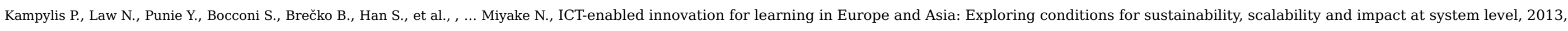

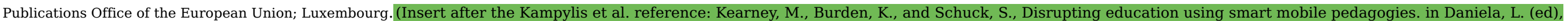

Didactics of Smart Pedagogy Smart Pedagogy for Technology Enhanced Learning, Springer, Germany, 2019, 139-157.)

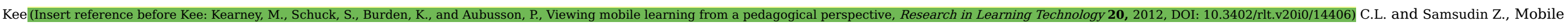

devices: Toys or learning tools for the 21st century teenagers?, TOJET - Turkish Online Journal of Educational Technology 13 (3), 2014.

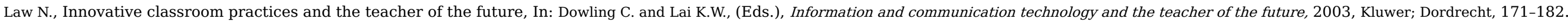

Law N., Chow Y. and Yuen H.K., Methodological approaches to comparing pedagogical innovations using technology, Education and Information Technologies 38, $2005,7-20$.

Lindfors E. and Hilmola A., Innovation learning in comprehensive education?, International Journal of Technology and Design Education 26, 2016, 373-389.

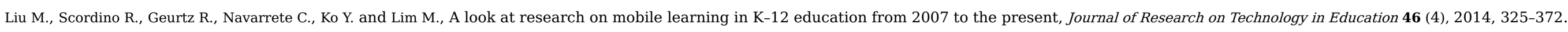

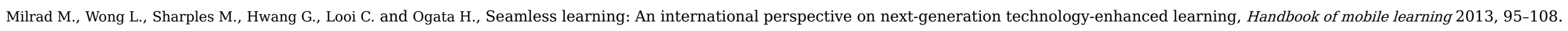

P21, 2007 P21, Framework for 21st century learning, Available from:http://www.p21.org/our-work/p21-framework, 2007.

Papert S., Technology in schools: To support the system or render it obsolete, 2004, Milken Family Foundation.

Parsons D., A mobile learning overview by timeline and mind map, 2014.

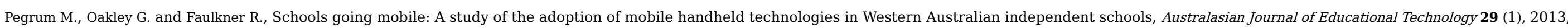
$66-81$.

Pereira O.R. and Rodrigues J.J., Survey and analysis of current mobile learning applications and technologies, ACM Computing Surveys 46 (2), $2013,27$.

Rushby N., An agenda for mobile learning, British Journal of Educational Technology 43 (3), 2012, 355-356.

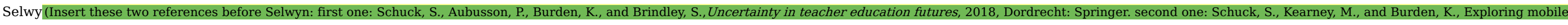

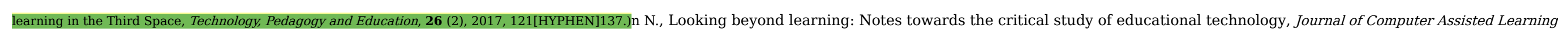
26 (1), 2010, 65-73.

Selwyn N., Education and technology: Key issues and debates, 2017, Bloomsbury Academic; New York.

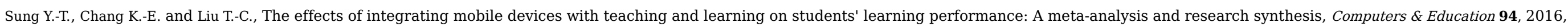

$252-275$.

Traxler J., Learning in a mobile age, International Journal of Mobile and Blended Learning 1 (1), 2009, 1-12.

Zhao Y., Pugh K., Sheldon S. and Byers J., Conditions for classroom technology innovation, Teachers College Record 104 (3), 2002, $482-515$.

\section{Appendix A. Supplementary data}

The following is the Supplementary data to this article: 


\section{Highlights}

- Fifty-seven high quality articles show varying levels of innovation in mobile pedagogies for school-aged learners.

- A continuum of innovation is presented in the context of mobile technology-mediated school-aged learning

- Examples are presented of innovative mobile pedagogies, for teachers designing effective mobile learning activities.

- A set of four criteria for identifying innovative mobile pedagogies are presented, developed from the literature.

- A scoring system is introduced for researchers/teachers interested in investigating innovative mobile learning practices.

\section{Queries and Answers}

Query: Please check the article title and correct if necessary.

Answer: this is correct

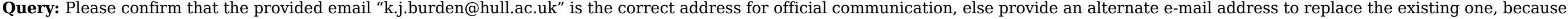
private e-mail addresses should not be used in articles as the address for communication.

Answer: This is correct

Query: Please check the hierarchy of the section headings.

Answer: This is correct

Query: Have we correctly interpreted the following funding source(s) and country names you cited in your article: EU, Turkey?

Answer: EU = European Union. Full title of project is: 'Designing and Evaluating Innovative Mobile Pedagogies': 2017-1-UK01-KA201-036781

Query: Please note that 'Tables, 3,8' were not cited in the text. Please check that the citation(s) suggested are in the appropriate place, and correct if necessary

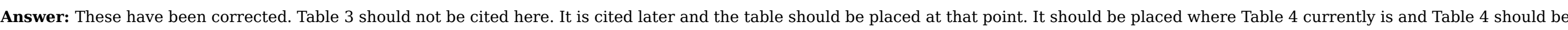
moved to below where it is cited. The Table 8 citation has also been corrected, it is now cited in the text below Table 7 and Table 8 could be moved to below the new citation

Query: The citation "Linfors \& Hilmola, 2016" has been changed to match the author name/date in the reference list. Please check.

Answer: This is now correct

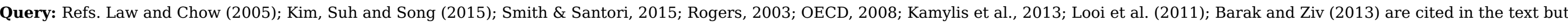
not provided in the reference list. Please provide them in the reference list or delete these citations from the text.

Answer: These are now provided in the reference list. Kamylis was an error- should be Kampylis, already cited.

Query: Please update ref. Authors, 2010; 2012; 2016; 2017; 2018; 2018a,b,; in press

Answer: These have updated in citations in text and added to the reference list. 
Query: Please provide the volume number or issue number or page range or article number for the bibliography in Ref(s). Heizer, 2018.

Answer: There is no volume number or issue number/page range or article number. This is an online article.

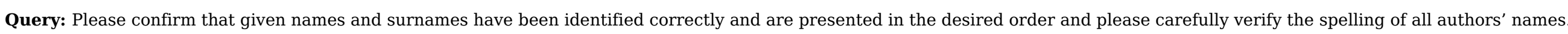
Answer: Yes 